\title{
Physician and medical student knowledge of hereditary cancer genetics in pediatrics
}

\author{
John Paul Govindavari ${ }^{3,4}$, David Tegay ${ }^{1}$, Donna McMahon ${ }^{2}$, Thomas Chan ${ }^{1}$, Vivian Chan ${ }^{3,4}$, Ambika Nath ${ }^{3}$, Mahin Rehman ${ }^{3,4}$, Neil Modi $^{3}$, and \\ Bhuma Krishnamachari ${ }^{1,3}$ \\ ${ }^{1}$ Department of Medicine, NYIT College of Osteopathic Medicine, Old Westbury, NY 11568, USA \\ ${ }^{2}$ Department of Educational Development \& Assessment, NYIT College of Osteopathic Medicine, Old Westbury NY 11568, USA \\ ${ }^{3}$ Division of Research, NYIT College of Osteopathic Medicine, Old Westbury, NY 11568, USA \\ ${ }^{4}$ Academic Medicine Scholars Program, NYIT College of Osteopathic Medicine, Old Westbury, NY 11568, USA
}

\begin{abstract}
Introduction: The deficit in knowledge regarding pediatric cancer genetics along the medical training spectrum is unknown.

Methods: 35 survey items were presented to 95 physicians and 145 students to evaluate their pediatric cancer syndrome knowledge.

Results: There were several questions which the majority of students and physicians did not answer correctly. Physicians were less likely than students to know some aspects of pediatric hereditary cancer. Physicians with genetics training were more likely to answer some items correctly.

Conclusions: Pediatric cancer genetics should be thoroughly addressed in medical school education and in CME training, as current knowledge may be limited. This may be an issue as the practicing physicians are the ones who are ultimately responsible for their patients.
\end{abstract}

\section{Introduction}

It is estimated that $5-10 \%$ of all pediatric cancer diagnoses are hereditary [1-7]. Assessing the pediatric population for hereditary cancer syndromes and early detection and treatment of cancer significantly enhances the likelihood for survival [2]. The general standard for risk assessment of hereditary cancers in the pediatric population involves taking a detailed family and medical history and if appropriate, genetic testing. This process requires physician knowledge of the features of each syndrome, as well as an understanding of when testing is appropriate [8].

The American Society of Clinical Oncology (ASCO) and the National Society of Genetic Counselors (NSGC) recommend that genetic testing be offered when the individual has personal or family history features suggestive of susceptibility to a genetic cancer condition. The test can be adequately interpreted, and the results will aid in diagnosis or influence the medical or surgical management of the patient or family members at risk of hereditary cancer [3,7]. The American Academy of Pediatrics stated that "genetic testing of children and adolescents to predict late-onset disorders is inappropriate when the genetic information has not been shown to reduce morbidity and mortality through interventions initiated in childhood" [9-10]. Thus, it is critical that physicians know when they should and should not recommend genetic testing for a child since not all genetic testing and interventions may be beneficial for certain genetic cancers.

Few pediatric hereditary predisposition syndromes have established protocols for testing and treatment. ${ }^{11}$ Syndromes with established protocols for assessment and medical management include Von Hippel-Lindau, Multiple Endocrine Neoplasias Types I and
II, PTEN Hamartoma Tumor Syndrome, Familial Paraganglioma/ Pheochromocytoma Syndrome, Peutz-Jegher Syndrome, Li-Fraumeni Syndrome, Beckwith Wiedmann Syndrome, neurofibromatosis type 1 , and hereditary retinoblastoma [1, 12-14]. Other syndromes do not have established protocols.

The level of physician knowledge regarding pediatric hereditary syndromes is currently unknown [1]. Additionally, knowledge in this area has not been assessed along the medical training continuum, from pre-clinical medical students to clinical medical students to clinical practice. Thus, the educational stages at which knowledge may be lacking is unknown. We sought to explore how increased levels of education and training affect knowledge about hereditary cancer and cancer syndromes in the pediatric population.

\section{Methods}

\section{Study design}

This study was approved by the New York Institute of Technology (NYIT) Institutional Review Board as an exempt study. A survey of 35 questions was administered to 95 physicians and 145 medical students evaluating their knowledge and practice patterns regarding hereditary

Correspondence to: Bhuma Krishnamachari, Department of Medicine, Department of Educational Development \& Assessment, NYIT College of Osteopathic Medicine, Old Westbury, NY 11568, USA, Tel: 516-686-7564; Fax: 516-686-3834; E-mail: bkrishna@nyit.edu

Key words: cancer genetics, medical education, physician knowledge

Received: May 21, 2016; Accepted: June 09, 2016; Published: June 13, 2016 
cancer syndromes. Subjects were recruited via email invitations sent from April 2014 to August 2014 through the NYIT College of Osteopathic Medicine (NYIT-COM) alumni association database and The American College of Osteopathic Pediatricians (ACOP) database.

\section{Survey items}

Knowledge-based questions were consistent with national clinical guidelines and general knowledge about hereditary pediatric cancer syndromes derived from the literature..$^{1-7,11-15}$ Survey questions were vetted by a multi-disciplinary team of physicians including two pediatricians, one family medicine physician and one internist $/$ medical geneticist. The questions were categorized as: General Knowledge, Colorectal Cancer, Retinoblastoma, Endocrine Cancer, and Other, which included the following syndromes: neurofibromatosis, LiFraumeni syndrome, Wilms tumor, Fanconi Anemia, Bloom syndrome, and ataxia telangiectasia. The specific items are shown in the tables.

\section{Statistical analyses}

Analyses were conducted using SAS version 9.1 (SAS Institute, Cary, NC). First- and second-year medical students were categorized as "preclinical", while third- and fourth-year students were categorized as "clinical." Data were analyzed comparing physicians with preclinical and clinical students. Additionally, physicians who reported having training in genetics were compared to those without training. Differences between groups were tested using a Chi-Square statistic for categorical variables and ANOVA for continuous variables. Because a statistically significant difference was found between groups, ageadjusted odds ratios and their 95\% confidence intervals (CIs) were estimated using unconditional logistic regression models. Odds ratios were calculated for those who answered each question correctly, versus incorrectly or indicating that they did not know the answer. Statistical significance was assessed using a two sided test at the alpha $=0.05$ level.

\section{Results}

From the NYIT-COM alumni association database, of the 3,975 members who received an email, 46 proceeded to complete the survey. From the ACOP, of the 450 who received an email, 52 completed the survey. Three participants were excluded for missing responses. Our physician response rate was $2.2 \%$. The survey was also sent to 1,199 medical students of NYIT-COM in their $1^{\text {st }}, 2^{\text {nd }}, 3^{\text {rd }}$ and $4^{\text {th }}$ years, and 148 completed the survey with a response rate of $12.3 \%$. Three students were excluded for missing responses. Demographics, field of practice, genetics training, and confidence in knowledge about genetics is shown in Table 1.
Table 2 shows the frequency distributions, age-adjusted odds ratios and $95 \%$ confidence intervals comparing knowledge of general topics in hereditary cancer genetics between preclinical students, clinical students, and physicians. For the statement "a hereditary gene mutation can occur for the first time in a child even if neither parent carries the mutation," practicing physicians were more likely to identify this as true than preclinical students (OR 6.55, 95\% CI 1.16, 37.14) but the same difference did not occur between practicing physicians and clinical students. Regarding the item, "Predictive genetic testing for adultonset conditions generally should be deferred unless an intervention initiated in childhood may reduce morbidity or mortality," practicing physicians were less likely than clinical students to identify this as true (OR 0.31, 95\% CI 0.11, 0.84).

Table 3 looks at the age-adjusted odds ratio, 95\% CI and p-values for each knowledge-based question concerning specific cancers and cancer syndromes. For the statement "For those with FAP, the penetrance of colonic adenomatous polyposis and colon cancer is virtually $100 \%$ in untreated individuals," clinical students were more likely to identify this as true than preclinical students (OR 5.57, 95\% CI 1.99, 15.55) and physicians were less likely to identify this as true than clinical students (OR 0.14, 95\% CI 0.04, 0.49). For the statement "For those with FAP, colon cancer screening should begin in childhood (under 18 years of age)," clinical students were more likely to identify this as true than preclinical students (OR 2.32, 95\% CI 1.09, 4.92). For the statement, "Lifelong colonoscopy and EGD every $2-3$ years starting in late teenage years is recommended for those with for Peutz-Jeghers syndrome," clinical students were more likely to identify this as true than preclinical students (OR 2.13, 95\% CI 1.03, 4.41). For the statement, "In regards to MEN 2B, RET molecular genetic testing should be performed as soon as possible after birth in all children known to be at risk," physicians were less likely to identify this as true than preclinical students (OR $0.16,95 \%$ CI $0.03,0.78$ ) and clinical students (OR 0.25, 95\% CI 0.08 , 0.86 ). For statement, "Wilms tumor can be associated with a hereditary syndrome," clinical students were more likely than preclinical students to identify this as true (OR 4.73, 95\% CI 1.91, 11.72). For statement, "Fanconi Anemia, Bloom syndrome, and ataxia telangiectasia are all cancer-predisposing syndromes that involve recessive genetic inheritance," physicians were more likely than preclinical students to identify this as true (OR 5.09, 95\% CI 1.22,21.32). There were some areas in which the majority of participants did not know the correct answer. For example, for the statement "a child with an adrenocortical tumor automatically has an increased risk for a hereditary cancer syndrome," $24.6 \%(\mathrm{n}=17)$ of preclinical students, $25.0 \%(\mathrm{n}=19)$ of clinical students and $28.4 \%(n=27)$ of physicians knew the correct answer.

Table 1: Demographics and Characteristics of Medical students and Physicians.

\begin{tabular}{|c|c|c|c|c|}
\hline & $\begin{array}{c}\text { Preclinical Students } \\
\text { (Years } 1 \text { and 2) } \\
\mathrm{N}=69\end{array}$ & $\begin{array}{c}\text { Clinical Students } \\
\text { (Years } 3 \text { and 4) } \\
N=76\end{array}$ & $\begin{array}{l}\text { Physicians } \\
\text { N=95 }\end{array}$ & P-value \\
\hline \multirow[t]{2}{*}{ Mean Age (SD) } & $25.02(3.02)$ & $27.07(4.00)$ & $45.51(12.59)$ & $<.0001$ \\
\hline & $\mathrm{N}(\%)$ & $\mathrm{N}(\%)$ & $\mathrm{N}(\%)$ & \\
\hline Gender: Female & $\begin{array}{c}42 \\
(60.90)\end{array}$ & $\begin{array}{c}49 \\
(64.50)\end{array}$ & $\begin{array}{c}51 \\
(53.70)\end{array}$ & 0.39 \\
\hline Pediatrics Medicine & NA & NA & $38(40.00)$ & NA \\
\hline Family Medicine & NA & NA & $17(17.90)$ & NA \\
\hline Other Pediatric Specialty & NA & NA & $40(42.10)$ & NA \\
\hline Had genetics training in medical school & NA & NA & $52(54.70)$ & NA \\
\hline Had genetics training during residency & NA & NA & $34(35.80)$ & NA \\
\hline Had CME genetics training & NA & NA & $18(18.90)$ & NA \\
\hline Feels confident in genetics knowledge & NA & NA & $28(29.50)$ & NA \\
\hline
\end{tabular}


Table 2: General Cancer Genetics Knowledge amongst Medical Students and Physicians.

\begin{tabular}{|c|c|c|c|c|c|c|}
\hline & $\begin{array}{l}\text { Preclinical } \\
\text { Students } \\
\text { (Years } 1 \text { and 2) } \\
\quad \mathrm{N}=69\end{array}$ & $\begin{array}{l}\text { Clinical } \\
\text { Students } \\
\text { (Years } 3 \text { and 4) } \\
\quad \mathrm{N}=76\end{array}$ & $\begin{array}{l}\text { Clinical vs Pre- } \\
\text { clinical } \\
\text { OR }(95 \% \text { CI) } \\
\text { p-value }\end{array}$ & $\begin{array}{l}\text { Physicians } \\
\quad \mathrm{N}=95\end{array}$ & $\begin{array}{l}\text { Physicians vs Pre- } \\
\text { clinical } \\
\text { OR }(95 \% \text { CI }) \\
\text { p-value }\end{array}$ & $\begin{array}{l}\text { Physicians vs } \\
\text { Clinical } \\
\text { OR }{ }^{\text {a }}(95 \% \text { CI }) \\
\text { p-value }\end{array}$ \\
\hline & $\mathrm{N}(\%)$ & N (\%) & & N (\%) & & \\
\hline \multicolumn{7}{|l|}{ Knew that: } \\
\hline $\begin{array}{l}\text { If a person is found to have a hereditary } \\
\text { cancer mutation, something can be done to } \\
\text { prevent the risk for cancer }\end{array}$ & $67(97.1)$ & $71(93.4)$ & $0.38(0.07,2.07)$ & $82(86.3)$ & $0.27(0.03,2.94)$ & $0.43(0.09,2.16)$ \\
\hline $\begin{array}{l}\text { Genetic sequencing will not detect all types } \\
\text { of genetic mutations }\end{array}$ & $61(88.4)$ & $67(88.2)$ & $1.19(0.42,3.41)$ & $72(75.8)$ & $0.65(0.11,3.80)$ & $2.05(0.41,10.21)$ \\
\hline $\begin{array}{l}\text { Molecular tests other than sequencing must } \\
\text { be used to detect gene deletions or re-arrangements }\end{array}$ & $43(62.3)$ & $38(50.0)$ & $0.64(0.32,1.27)$ & $38(40.0)$ & $0.57(0.17,1.90)$ & $0.56(0.21,1.50)$ \\
\hline $\begin{array}{l}\text { A hereditary gene mutation can occur for the first time in a child } \\
\text { even if neither parent carries the mutation }\end{array}$ & $50(72.5)$ & $67(88.2)$ & $3.57(1.37,9.32)$ & $83(87.4)$ & $6.55(1.16,37.14)$ & $1.04(0.26,4.18)$ \\
\hline $\begin{array}{l}\text { The same gene mutation can sometimes cause different clinical } \\
\text { presentations in different children. }\end{array}$ & $68(98.6)$ & $74(97.4)$ & $0.44(0.04,5.12)$ & 87 (91.6) & $0.06(0.003,1.21)$ & $0.18(0.02,1.47)$ \\
\hline $\begin{array}{l}\text { Around } 10 \% \text { of all cancer diagnoses in the pediatric age range } \\
\text { occur in children with a hereditary genetic mutation. }\end{array}$ & $26(37.7)$ & $27(35.5)$ & $0.89(0.44,1.79)$ & $30(31.6)$ & $1.19(0.34,4.16)$ & $1.06(0.39,2.89)$ \\
\hline $\begin{array}{l}\text { There are not established protocols for testing and treating all } \\
\text { pediatric hereditary genetic cancers }\end{array}$ & $27(39.1)$ & $38(50.0)$ & $1.65(0.83,3.29)$ & $32(33.7)$ & $1.15(0.33,4.01)$ & $0.45(0.16,1.24)$ \\
\hline $\begin{array}{l}\text { Predictive genetic testing for adult-onset conditions generally } \\
\text { should be deferred unless an intervention initiated in childhood } \\
\text { may reduce morbidity or mortality. }\end{array}$ & $42(60.9)$ & $52(68.4)$ & $1.38(0.66,2.89)$ & $39(41.1)$ & $0.29(0.08,1.07)$ & $0.31(0.11,0.84)$ \\
\hline $\begin{array}{l}\text { Bilateral tumors in paired organs, multifocal tumors, and multiple } \\
\text { primary cancers in a single individual often indicate an underlying } \\
\text { or inherited genetic cause of cancer. }\end{array}$ & $52(75.4)$ & $57(75.0)$ & $1.09(0.48,2.51)$ & $59(62.1)$ & $0.58(0.15,2.27)$ & $0.92(0.31,2.74)$ \\
\hline $\begin{array}{l}\text { An earlier age of cancer diagnosis can be a feature of an } \\
\text { underlying or inherited genetic cause of cancer. }\end{array}$ & $52(75.4)$ & $57(75.0)$ & $0.99(0.43,2.29)$ & $56(58.9)$ & $1.76(0.37,8.32)$ & $0.87(0.29,2.55)$ \\
\hline
\end{tabular}

aAjusted for age

Table 4 shows the age-adjusted odds ratio, 95\% CI and p-values for knowledge-based questions concerning general statements about cancer genetics and syndromes for those who did and did not receive genetics training at different points of their medical career. There were no significant differences between those with and without training.

Table 5 looks at the age-adjusted odds ratio, 95\% CI and p-values for each knowledge-based question about specific cancers and cancer syndromes for physicians who did and did not receive genetics training at different points of their medical career. Any training in cancer genetics was associated with an increased likelihood of identifying that, "A 16-year-old individual found to have multiple adenomatous polyps at a colonoscopy is at a high risk for a hereditary colon cancer syndrome even in the absence of a significant family history" (OR 3.86, $95 \%$ CI 1.29, 11.57). Similarly, training was associated with an increased likelihood of knowing that, "Those with juvenile polyposis syndrome should have lifelong monitoring for rectal bleeding," (OR 2.97, 95\% CI 1.10, 8.01). Those with training, compared to those without, were also more likely to know that, "Those with neurofibromatosis type 2 should have cranial MRI annually beginning at age 10-12 years until at least the fourth decade of life," (OR $2.7595 \%$ CI 1.06, 7.13). No other significant differences were found between the two groups.

\section{Discussion}

Our results show that knowledge is lacking at all stages of medical education in several areas of pediatric cancer genetics. In some cases, medical students had greater knowledge than practicing physicians, which may be due to a discontinuation of certain aspects of medical education once medical school ends. This may be an issue as the practicing physicians are the ones who are ultimately responsible for their patients. CME training is then crucial in this area.
Previous studies support our findings for the need of CME training. A recent study showed that less than half of general pediatricians felt competent in providing healthcare to patients related to genetics and genomics. Additionally, less than half reported access to adequate resources to aid in ordering appropriate testing. Similarly, approximately $40 \%$ of pediatricians were aware of only one or none of twelve national resources regarding genetic information and services [16].

Studies also highlight the need for cancer genetics training at a basic level, specifically for taking and interpreting family history at the pediatric residency level [16-18]. A study comparing residents in internal medicine-pediatrics and pediatrics showed no increase in knowledge of cancer genetic-related information with higher levels of training [17]. Rather, pediatric residents were less likely to ask about family history of early colorectal cancer or colon polyps compared to medicine-pediatric residents, which may indicate inadequate training of hereditary cancer within the field of pediatrics itself [17]. Our study found that CME training in cancer genetics was associated with increased knowledge, suggesting that more CME training needs to be made available to physicians in order to ensure patients with specific genetic needs receive sufficient and appropriate care. Pediatricians have cited CME opportunities related to genetics and increased understanding of genetics as factors that would provide incentive to more effectively integrate genetic-based medicine into their practices [16].

Our study was subject to certain limitations. It relied on student and physician self-report of their area of medical practice and exposure to genetic testing and training. We were unable to identify the actual content or intensity of genetics education received throughout medical school, residency, or CME; this would have been useful considering the number of students in the same years that indicated different responses 
Table 3: Hereditary Cancer Syndromes Knowledge amongst Medical Students and Physicians.

\begin{tabular}{|c|c|c|c|c|c|c|}
\hline & $\begin{array}{c}\text { Preclinical } \\
\text { Students } \\
\text { (Years 1 } \\
\text { and 2) } \\
\mathrm{N}=69\end{array}$ & $\begin{array}{c}\text { Clinical } \\
\text { Students } \\
\text { (Years } 3 \\
\text { and 4) } \\
N=76\end{array}$ & $\begin{array}{l}\text { Clinical vs Pre- } \\
\text { clinical } \\
\text { OR }^{\text {b }}(95 \% \text { CI }) \\
\text { p-value }\end{array}$ & $\begin{array}{c}\text { Physicians } \\
\text { N=95 }\end{array}$ & $\begin{array}{l}\text { Physicians vs } \\
\text { Pre-clinical } \\
\text { OR }(95 \% \text { CI) } \\
\text { p-value }\end{array}$ & $\begin{array}{l}\text { Physicians vs } \\
\text { Clinical } \\
\text { OR }(95 \% \text { CI }) \\
\text { p-value }\end{array}$ \\
\hline Knew that: & $\mathrm{N}(\%)$ & $\mathrm{N}(\%)$ & & $\mathrm{N}(\%)$ & & \\
\hline \multicolumn{7}{|l|}{ Colorectal Cancer } \\
\hline $\begin{array}{l}\text { A } 16 \text {-year-old individual found to have multiple adenomatous polyps at a } \\
\text { colonoscopy is at a high risk for a hereditary colon cancer syndrome even in the } \\
\text { absence of a significant family history }\end{array}$ & $52(75.4)$ & $62(81.6)$ & $1.15(0.51,2.61)$ & $78(82.1)$ & $0.90(0.20,4.09)$ & $1.06(0.29,3.95)$ \\
\hline $\begin{array}{l}\text { Offspring of an affected individual are not at a } 10 \% \text { risk of inheriting the disease- } \\
\text { causing mutation in adenomatous polyposis coli }\end{array}$ & $43(62.3)$ & $35(46.1)$ & $0.53(0.27,1.07)$ & $26(27.4)$ & $0.29(0.08,1.04)$ & $0.76(0.29,2.03)$ \\
\hline $\begin{array}{l}\text { For those with FAP, the penetrance of colonic adenomatous polyposis and colon } \\
\text { cancer is virtually } 100 \% \text { in untreated individuals. }\end{array}$ & $45(65.2)$ & $69(90.8)$ & $5.57(1.99,15.55)$ & $44(46.3)$ & $0.48(0.14,1.69)$ & $0.14(0.04,0.49)$ \\
\hline $\begin{array}{l}\text { For those with FAP, colon cancer screening should begin in childhood (under } 18 \\
\text { years of age) }\end{array}$ & $39(56.5)$ & $56(73.7)$ & $2.32(1.09,4.92)$ & $62(65.3)$ & $1.38(0.36,5.31)$ & $1.23(0.38,3.97)$ \\
\hline $\begin{array}{l}\text { Those with juvenile polyposis syndrome should have lifelong monitoring for } \\
\text { rectal bleeding }\end{array}$ & $45(65.2)$ & $51(67.1)$ & $1.13(0.542 .40)$ & $63(66.3)$ & $0.63(0.17,2.30)$ & $1.04(0.37,2.89)$ \\
\hline $\begin{array}{l}\text { Lifelong colonoscopy and EGD every } 2-3 \text { y starting in late teenage years is } \\
\text { recommended for those with for Peutz-Jeghers syndrome }\end{array}$ & $37(53.6)$ & $54(71.1)$ & $2.13(1.03,4.41)$ & $54(56.8)$ & $1.16(0.34,3.90)$ & $0.54(0.20,1.49)$ \\
\hline \multicolumn{7}{|l|}{ Retinoblastoma } \\
\hline $\begin{array}{l}\text { Children with retinoblastoma most often initially present with white pupillary } \\
\text { reflex (leukocoria). }\end{array}$ & $52(75.4)$ & $60(78.9)$ & $1.32(0.59,2.97)$ & $67(70.5)$ & $0.86(0.23,3.23)$ & $0.65(0.21,1.97)$ \\
\hline Retinoblastoma is most often diagnosed prior to the age of 5 . & $54(78.3)$ & $64(84.2)$ & $1.49(0.62,3.60)$ & $72(75.8)$ & $0.77(0.18,3.32)$ & $0.61(0.17,2.15)$ \\
\hline $\begin{array}{l}\text { The risk for other specific extra ocular primary neoplasms is increased in } \\
\text { individuals with heritable Rb (Retinoblastoma gene) and in heterozygous carriers } \\
\text { of a cancer-predisposing RB1 mutation. }\end{array}$ & $48(69.6)$ & $48(63.2)$ & $0.68(0.33,1.41)$ & $44(46.3)$ & $0.33(0.09,1.18)$ & $0.50(0.18,1.34)$ \\
\hline $\begin{array}{l}\text { Second primary cancers associated with retinoblastoma include osteosarcomas, } \\
\text { soft tissue sarcomas (mostly leiomyosarcomas and rhabdomyosarcomas), and } \\
\text { melanomas, all of which may present during adolescence }\end{array}$ & $52(75.4)$ & $52(68.4)$ & $0.74(0.34,1.60)$ & $40(42.1)$ & $0.39(0.11,1.39)$ & $0.61(0.23,1.66)$ \\
\hline $\begin{array}{l}\text { Genetic screening of the RB1 gene should be considered in any child with } \\
\text { bilateral RB }\end{array}$ & $58(86.6)$ & $63(85.1)$ & $1.02(0.36,2.88)$ & $55(58.5)$ & $0.53(0.12,2.42)$ & $1.14(0.32,4.03)$ \\
\hline $\begin{array}{l}\text { Genetic screening of the RB1 gene should be considered in any child who } \\
\text { presents with disease at a young age }(<1-2 \text { years })\end{array}$ & $52(75.4)$ & $59(77.6)$ & $0.92(0.39,2.18)$ & $48(50.5)$ & $0.29(0.07,1.21)$ & $0.60(0.20,1.77)$ \\
\hline \multicolumn{7}{|l|}{ Endocrine Cancers } \\
\hline $\begin{array}{l}\text { A child with an adrenocortical tumor automatically has an increased risk for a } \\
\text { hereditary cancer syndrome }\end{array}$ & $17(24.6)$ & $19(25.0)$ & $0.89(0.40,1.99)$ & $27(28.4)$ & $2.05(0.58,7.25)$ & $2.18(0.77,6.21)$ \\
\hline $\begin{array}{l}\text { The diagnostic criteria for multiple endocrine neoplasia type } 1 \text { (MEN1) syndrome } \\
\text { are the presence of two of the following three endocrine tumors, which may } \\
\text { become evident either by overproduction of polypeptide hormones or by growth } \\
\text { of the tumor itself. }\end{array}$ & $43(62.3)$ & $59(77.6)$ & $2.05(0.95,4.42)$ & $63(66.3)$ & $5.23(0.94,29.02)$ & $0.83(0.25,2.71)$ \\
\hline $\begin{array}{l}\text { In regards to MEN2A, RET molecular genetic testing should be offered to at-risk } \\
\text { children by age five years, since MTC has been documented in childhood }\end{array}$ & $33(47.8)$ & $41(53.9)$ & $1.40(0.70,2.80)$ & $34(35.8)$ & $1.17(0.34,4.00)$ & $0.53(0.20,1.41)$ \\
\hline $\begin{array}{l}\text { In regards to MEN } 2 \mathrm{~B} \text {, RET molecular genetic testing should be performed as } \\
\text { soon as possible after birth in all children known to be at risk }\end{array}$ & $26(37.7)$ & $32(42.1)$ & $1.15(0.57,2.32)$ & $19(20.0)$ & $0.16(0.03,0.78)$ & $0.25(0.08,0.86)$ \\
\hline $\begin{array}{l}\text { Pediatric patients with malignant paragangliomas (PGL) or pheochromocytomas } \\
\text { (PCC) may have an underlying hereditary mutation }\end{array}$ & $31(44.9)$ & $33(43.4)$ & $1.02(0.51,2.04)$ & $21(22.1)$ & $0.58(0.16,2.12)$ & $0.71(0.26,1.91)$ \\
\hline \multicolumn{7}{|l|}{ Other } \\
\hline The risks for cancer in Li-Fraumeni syndrome are relatively low. & $35(50.7)$ & $46(60.5)$ & $1.75(0.86,3.54)$ & $27(28.4)$ & $1.17(0.34,3.98)$ & $1.21(0.44,3.35)$ \\
\hline Wilmstumor can be associated with a hereditary syndrome. & $43(62.3)$ & $67(88.2)$ & $4.73(1.91,11.72)$ & $70(73.7)$ & $3.45(0.74,16.04)$ & $0.48(0.12,1.91)$ \\
\hline $\begin{array}{l}\text { FanconiAnemia, Bloom syndrome and ataxia telangiectasia are all cancer- } \\
\text { predisposing syndromes that involve recessive genetic inheritance. }\end{array}$ & $34(49.3)$ & $47(61.8)$ & $1.71(0.85,3.42)$ & $59(62.1)$ & $5.09(1.22,21.32)$ & $1.84(0.62,5.47)$ \\
\hline $\begin{array}{l}\text { Those with neurofibromatosis type } 2 \text { should have cranial MRI annually beginning } \\
\text { at age } 10-12 \text { years until at least the fourth decade of life. }\end{array}$ & $34(49.3)$ & $31(40.8)$ & $0.87(0.43,1.75)$ & $44(46.3)$ & $1.27(0.38,4.32)$ & $1.50(0.56,4.03)$ \\
\hline
\end{tabular}

${ }^{\mathrm{b}}$ Adjusted for age

regarding exposure to genetics training. Regarding physician selfreported medical specialty, most of the respondents indicated they were PCPs (General Pediatricians or Family Medicine practitioners), but some indicated subspecialties or other specialties without clarification. An additional limitation was that student participants came from a single institution and our results might not fully reflect the knowledge of medical students nationally. Lastly, our limited sample size and low response rate may have introduced bias, as physicians and students who did not respond to the survey may also have been less likely to have actively participated in genetics education or have interests in future education concerning the topics addressed in the study.

\section{Conclusion}

Notwithstanding these limitations, the strength of this study lies in its focus on physician and student knowledge concerning pediatric hereditary cancer syndromes, something not widely assessed previously. The existing medical literature has emphasized the need 
Table 4: Physicians with and without Genetics Training-General Genetics Knowledge.

\begin{tabular}{|c|c|c|c|}
\hline & $\begin{array}{l}\text { Any Training } \\
\quad \mathrm{N}=66\end{array}$ & $\begin{array}{l}\text { No training } \\
\quad \mathbf{N}=\mathbf{2 9}\end{array}$ & $\mathrm{OR}^{\mathrm{c}}(\mathbf{9 5} \% \mathrm{CI})$ \\
\hline & $\mathrm{N}(\%)$ & $\mathrm{N}(\%)$ & \\
\hline \multicolumn{4}{|l|}{ Knew that: } \\
\hline $\begin{array}{l}\text { If a person is found to have a hereditary cancer mutation, something can be done } \\
\text { to prevent the risk for cancer }\end{array}$ & $59(89.4)$ & $19(65.5)$ & $2.19(0.64,7.47)$ \\
\hline Genetic sequencing will not detect all types of genetic mutations & $51(77.3)$ & $21(72.4)$ & $0.99(0.36,2.77)$ \\
\hline $\begin{array}{l}\text { Molecular tests other than sequencing must be used to detect gene deletions } \\
\text { or re-arrangements }\end{array}$ & $28(42.4)$ & $10(34.5)$ & $1.35(0.55,3.31)$ \\
\hline $\begin{array}{l}\text { A hereditary gene mutation can occur for the first time in a child even if neither parent } \\
\text { carries the mutation }\end{array}$ & $58(87.9)$ & $25(86.2)$ & $1.06(0.28,4.00)$ \\
\hline The same gene mutation can sometimes cause different clinical presentations in different children. & $62(94.0)$ & $25(86.2)$ & $1.99(0.43,9.17)$ \\
\hline $\begin{array}{l}\text { Around } 10 \% \text { of all cancer diagnoses in the pediatric age range occur in children with } \\
\text { a hereditary genetic mutation. }\end{array}$ & $23(34.8)$ & $7(24.1)$ & $1.54(0.56,4.27)$ \\
\hline There are not established protocols for testing and treating all pediatric hereditary genetic cancers & $27(40.9)$ & $5(17.2)$ & $4.47(1.41,14.24)$ \\
\hline $\begin{array}{l}\text { Predictive genetic testing for adult-onset conditions generally should be deferred unless } \\
\text { an intervention initiated in childhood may reduce morbidity or mortality. }\end{array}$ & $28(42.4)$ & $11(37.9)$ & $1.30(0.52,3.22)$ \\
\hline $\begin{array}{l}\text { Bilateral tumors in paired organs, multifocal tumors, and multiple primary cancers in a } \\
\text { single individual often indicate an underlying or inherited genetic cause of cancer. }\end{array}$ & $43(65.2)$ & $16(55.2)$ & $1.48(0.59,3.73)$ \\
\hline $\begin{array}{l}\text { An earlier age of cancer diagnosis can be a feature of an underlying or inherited genetic } \\
\text { cause of cancer. }\end{array}$ & $41(62.1)$ & $15(51.7)$ & $1.44(0.56,3.69)$ \\
\hline
\end{tabular}

${ }^{\mathrm{c}}$ Adjusted for age

Table 5: Knowledge of Hereditary Cancer Syndromes in Physicians With and Without Genetics Training.

Knew that:

\section{Colorectal Cancer}

A 16-year-old individual found to have multiple adenomatous polyps at a colonoscopy is at a high risk for a hereditary colon cancer syndrome even in the absence of a significant family history

Offspring of an affected individual are not at a $10 \%$ risk of inheriting the disease-causing mutation in adenomatous polyposis coli

For those with FAP, the penetrance of colonic adenomatous polyposis and colon cancer is virtually $100 \%$ in untreated individuals. For those with FAP, colon cancer screening should begin in childhood (under 18 years of age)

That those with juvenile polyposis syndrome should have lifelong monitoring for rectal bleeding

That lifelong colonoscopy and EGD every 2-3 y starting in late teenage years is recommended for those with for Peutz-Jeghers syndrome

\section{Retinoblastoma}

That children with retinoblastoma most often initially present with white pupillary reflex (leukocoria)

That retinoblastoma is most often diagnosed prior to the age of 5 .

That the risk for other specific extra ocular primary neoplasms is increased in individuals with heritable Rb (Retinoblastoma gene) and in heterozygous carriers of a cancer-predisposing RB1 mutation.

That second primary cancers associated with retinoblastoma include osteosarcomas, soft tissue sarcomas (mostly leiomyosarcomas and rhabdomyosarcomas), and melanomas, all of which may present during adolescence

That genetic screening of the RB1 gene should be considered in any child with bilateral RB

That genetic screening of the RB1 gene should be considered in any child who presents with disease at a young age $(<1-2$ years) Endocrine Cancers

That a child with an adrenocortical tumor automatically has an increased risk for a hereditary cancer syndrome

That the diagnostic criteria for multiple endocrine neoplasia type 1 (MEN1) syndrome are the presence of two of the following three endocrine tumors, which may become evident either by overproduction of polypeptide hormones or by growth of the tumor itself.

That in regards to MEN2A, RET molecular genetic testing should be offered to at-risk children by age five years, since MTC has been documented in childhood

That in regards to MEN 2B, RET molecular genetic testing should be performed as soon as possible after birth in all children known to be at risk

That pediatric patients with malignant paragangliomas (PGL) or pheochromocytomas (PCC) most likely do not have an underlying hereditary mutation

Other

The risks for cancer in Li-Fraumeni syndrome are relatively low.

Wilmstumor can be associated with a hereditary syndrome.

FanconiAnemia, Bloom syndrome and ataxia telangiectasia are all cancer-predisposing syndromes that involve recessive genetic inheritance.

Those with neurofibromatosis type 2 should have cranial MRI annually beginning at age 10-12 years until at least the fourth decade of life.

${ }^{\mathrm{d}}$ Adjusted for age

\begin{tabular}{|c|c|c|}
\hline $\begin{array}{c}\text { Any Training } \\
\qquad N=66\end{array}$ & $\begin{array}{c}\text { No training } \\
\mathbf{N}=\mathbf{2 9}\end{array}$ & OR $^{\mathrm{d}}(95 \% \mathrm{CI})$ \\
\hline N (\%) & N (\%) & \\
\hline $58(87.9)$ & $20(69.0)$ & $3.86(1.29,11.57)$ \\
\hline $20(29.0)$ & $85(30.6)$ & $0.97(0.33,2.85)$ \\
\hline $32(48.5)$ & $12(41.4)$ & $1.17(0.46,2.99)$ \\
\hline 47 (71.2) & $15(51.7)$ & $2.60(0.98,6.86)$ \\
\hline 47 (71.2) & $16(55.2)$ & $2.97(1.10,8.01)$ \\
\hline $39(59.0)$ & $15(51.7)$ & $1.59(0.64,3.99)$ \\
\hline $46(69.7)$ & $21(72.4)$ & $0.78(0.28,2.19)$ \\
\hline 48 (72.7) & $24(82.8)$ & $0.41(0.13,1.28)$ \\
\hline $35(53.0)$ & $9(31.0)$ & $2.33(0.90,6.03)$ \\
\hline $27(40.9)$ & $13(44.8)$ & $0.66(0.26,1.67)$ \\
\hline $41(62.1)$ & $11(37.9)$ & $2.37(0.93,6.06)$ \\
\hline $38(57.6)$ & $10(34.5)$ & $2.27(0.89,5.78)$ \\
\hline $22(33.3)$ & $5(17.2)$ & $2.47(0.80,7.63)$ \\
\hline 48 (72.7) & $15(51.7)$ & $1.57(0.60,4.16)$ \\
\hline $24(36.4)$ & $10(34.5)$ & $1.12(0.44,2.84)$ \\
\hline $15(22.7)$ & $4(13.8)$ & $\begin{array}{c}3.24(0.90) \\
11.58)\end{array}$ \\
\hline $13(19.7)$ & $8(27.6)$ & $0.49(0.16,1.46)$ \\
\hline $20(30.3)$ & $6(20.7)$ & $1.88(0.53,6.66)$ \\
\hline $50(75.8)$ & $20(69.0)$ & $1.29(0.46,3.63)$ \\
\hline $42(63.6)$ & $17(58.6)$ & $1.12(0.43,2.92)$ \\
\hline $34(51.5)$ & $10(34.5)$ & $2.75(1.06,7.13)$ \\
\hline
\end{tabular}


for more intensive and comprehensive cancer genetic education concerning the pediatric population. Our results further underscored this need.

\section{Lessons for Practice:}

Continuing medical education on pediatric hereditary cancer should be provided to practicing physicians

\section{Disclosure}

The authors declare no conflict of interest.

\section{References}

1. Knapke S, Zelley K, Nichols KE, Kohlmann W, Schiffman JD (2012) Identification, management, and evaluation of children with cancer-predisposition syndromes. Am Soc Clin Oncol Educ Book [Crossref]

2. Schiffman J, Geller A Means, L Means, and V Means (2013) Update on Pediatric Cancer Predisposition Syndromes. Pediatr Blood Cancer 60: 1247-1252.

3. Teplick A, Kowalski M, Biegel JA, Nichols KE (2011) Educational paper: screening in cancer predisposition syndromes: guidelines for the general pediatrician. Eur J Pediatr 170: 285-294. [Crossref]

4. Testa JR, Malkin D, Schiffman JD (2013) Connecting molecular pathways to hereditary cancer risk syndromes. Am Soc Clin Oncol Educ Book. [Crossref]

5. Field M, Shanley S, Kirk J (2007) Inherited cancer susceptibility syndromes in paediatric practice. J Paediatr Child Health 43: 219-229. [Crossref]

6. American Society of Clinical Oncology (2003) American Society of Clinical Oncology policy statement update: genetic testing for cancer susceptibility. J Clin Oncol 21 2397-2406. [Crossref]

7. Riley BD, Culver JO, Skrzynia C, Senter LA, Peters JA, et al. (2012) Essential elements of genetic cancer risk assessment, counseling, and testing: updated recommendations of the National Society of Genetic Counselors. J Genet Couns 21:151-161.

8. Ross LF, Saal HM, David KL, Anderson RR (2013) American Academy of Pediatrics; American College of Medical Genetics and Genomics Technical report: Ethical and policy issues in genetic testing and screening of children. Genet Med 15: 234-245. [Crossref]

9. Wilfond B, Ross LF (2009) From genetics to genomics: ethics, policy, and parental decision-making. J Pediatr Psychol 34: 639-647. [Crossref]

10. Tarini BA, Tercyak KP, Wilfond BS (2011) Commentary: Children and predictive genomic testing: disease prevention, research protection, and our future. $J$ Pediatr Psychol 36: 1113-1121. [Crossref]

11. D’Orazio JA (2010) Inherited cancer syndromes in children and young adults. J Pediat Hematol Oncol 32: 195-228. [Crossref]

12. National Comprehensive Cancer Network (2015) NCCN Clinical Practice Guidelines in Oncology: Genetic/Familial High-Risk Assessment: Breast and Ovarian, v2.2014.

13. National Comprehensive Cancer Network (2015) NCCN Clinical Practice Guidelines in Oncology: Genetic/Familial High-Risk Assessment: Colorectal, v2.2014.

14. National Comprehensive Cancer Network. NCCN Clinical Practice Guidelines in Oncology: Neuroendocrine Tumors, v1.2015.

15. Pletcher BA, Toriello HV, Noblin SJ, Seaver LH, Driscoll DA, et al. (2007) Indications for genetic referral: a guide for healthcare providers. Genet Med 9: 385-389. [Crossref]

16. Rinke ML, Mikat-Stevens N, Saul R, Driscoll A, Healy J, et al. (2014) Genetic services and attitudes in primary care pediatrics. Am J Med Genet A 164A: 449-455. [Crossref]

17. Stoner J, Qi Y, Erdman S, Attard T (2009) A Web-Based Assessment of Pediatrics Resident Medical Knowledge in Childhood Hereditary Gastrointestinal Cancer Predisposing Syndromes. J Cancer Educ 24: 254-256.

18. Trotter TL, Martin HM (2007) Family history in pediatric primary care. Pediatrics 120 Suppl 2: S60-65. [Crossref]

Copyright: (C2016 Govindavari JP. This is an open-access article distributed under the terms of the Creative Commons Attribution License, which permits unrestricted use, distribution, and reproduction in any medium, provided the original author and source are credited. 